\title{
Short communication: Rumination and feeding behaviors differ between healthy and sick dairy cows during the transition period
}

\author{
K. Schirmann, ${ }^{\star} \dagger$ D. M. Weary, ${ }^{*}$ W. Heuwieser, $\dagger^{1}$ N. Chapinal, ${ }^{*}$ R. L. A. Cerri,ł and M. A. G. von Keyserlingk ${ }^{* 2}$ \\ *Animal Welfare Program, Faculty of Land and Food Systems, University of British Columbia, 2357 Main Mall, Vancouver, BC, V6T 1Z4, Canada \\ †Clinic for Animal Reproduction, Faculty of Veterinary Medicine, Freie Universität Berlin, Königsweg 65, 14163 Berlin, Germany \\ ‡Faculty of Land and Food Systems, University of British Columbia, 2357 Main Mall, Vancouver, BC, V6T 1Z4, Canada
}

\section{ABSTRACT}

The objectives of this study were: (1) to describe the rumination and feeding behavior of freestall-housed Holstein dairy cows in the weeks around parturition, and (2) to determine the relationship between postpartum disease and precalving rumination and feeding behavior. Eighty cows were enrolled at approximately 2 wk (18 $\pm 7 \mathrm{~d}$, mean \pm standard deviation) before calving. Using automatic monitoring systems, rumination and feeding behavior were recorded continuously from $10 \mathrm{~d}$ before until $3 \mathrm{wk}$ after calving. Postpartum health checks were performed each day, and metritis assessment was conducted 2 times/wk. Blood $\beta$-hydroxybutyrate was measured 3 times/week, and cows with $\geq 1.2 \mathrm{mmol} / \mathrm{L}$ during the first $14 \mathrm{~d}$ postpartum were diagnosed as having subclinical ketosis. The final data set included 64 cows in 5 groups: healthy (n $=20)$, metritis $(\mathrm{n}=18)$, subclinical ketosis (SCK; $\mathrm{n}$ $=9)$, metritis $+\operatorname{SCK}(\mathrm{n}=9)$, and $>1$ health problem and not included before (MULT, $\mathrm{n}=8$ ). We compared rumination and feeding data between healthy cows and the 4 categories of ill animals in each of 4 periods relative to calving: precalving ( $\mathrm{d}-7$ to -2 ), period 1 (d 3 to 8 postpartum), period 2 (d 9 to 14 postpartum), and period 3 (d 15 to 20 postpartum). Cows with SCK spent less time ruminating during the precalving period. Compared with healthy cows, those with SCK and metritis+SCK had lower dry matter intake during the precalving period and continued to eat less until d 14 and d 20 postpartum, respectively. Cows with metritis and MULT cows had lower dry matter intake during the first 2 wk postpartum. Precalving feeding time was lower for SCK, metritis+SCK, and MULT cows compared with healthy cows. The difference in feeding time

Received October 20, 2015

Accepted August 18, 2016.

${ }^{1}$ Current address: Department of Population Medicine and Diagnostic Science, College of Veterinary Medicine, Cornell University, Ithaca, NY.

${ }^{2}$ Corresponding author: nina@mail.ubc.ca between healthy and metritis+SCK cows had disappeared by period 2 and between all health categories except MULT by period 3. MULT cows visited the feed bins less often and were less often replaced at the feed bin throughout all 4 periods of the study. Automatic monitoring of intake and rumination showed promise for the detection of health problems after calving. We observed differences in precalving rumination and feeding behavior. Further research is necessary to better understand the onset of behavioral changes and the relationship between rumination and disease.

Key words: rumination collar, subclinical ketosis, metritis, automatic monitoring, disease

\section{Short Communication}

There is growing interest in how to use behavior to identify disease early and, ideally, automatically (see reviews: Weary et al., 2009; von Keyserlingk and Weary, 2010). In this context, feeding and rumination behavior are of particular interest. Feeding behavior describes the parameters involved in active feeding, such as the time spent feeding, the amount of feed intake, and the rate at which feed is ingested. Rumination behavior (needed for particle breakdown and rumen $\mathrm{pH}$ balance) describes the time spent ruminating previously ingested feed and consists of regurgitation, re-insalivation, remastication, and reswallowing of feed boluses. Feeding behavior is sensitive to management situations and health, especially during the transition period (von Keyserlingk and Weary, 2010). For example, Huzzey et al. (2007) and Goldhawk et al. (2009) found that changes in DMI and time spent feeding in the days before calving identified cows that were later diagnosed with metritis or subclinical ketosis (SCK) postpartum, respectively. Rumination activity has been linked to the detection of anxiety (Bristow and Holmes, 2007), distress (Schirmann et al., 2011), disease (Fogsgaard et al., 2012), and metabolic disorders (Hansen et al., 2003; DeVries et al., 2009). Recent work has also shown some promise in the use of rumination as an indicator for dis- 
ease during the transition period (Soriani et al., 2012; Calamari et al., 2014; Kaufman et al., 2016). However, none of these studies monitored feeding behavior. To date, no information is available on how health-related differences in time spent ruminating during the transition period are related to feeding behavior.

The objectives of this study were to use rumination and feeding data captured using validated technologies (1) to describe time spent ruminating and feeding behavior (consisting of DMI, time spent feeding, feeding rate, and visits to the feed bin) of freestall-housed dairy cows in the weeks before and after parturition, and (2) to determine the relationship between postpartum disease and rumination behavior before and after calving.

This study was conducted at the University of British Columbia's Dairy Education and Research Centre (Agassiz, BC, Canada). Animals were managed and cared for according to the guidelines set by the $\mathrm{Ca}$ nadian Council on Animal Care (2009). A total of 80 multiparous Holstein cows (parity $3.3 \pm 1.6$, mean \pm SD) were enrolled. Primiparous cows were excluded, because research has shown differences in behavior compared with multiparous animals (Hasegawa et al., 1997; González et al., 2003). Cows were enrolled at $18 \pm 7 \mathrm{~d}$ (mean $\pm \mathrm{SD}$ ) before calving. Behavior and health status were recorded for 5 wk (2 wk before calving to 3 wk after calving). Cows were kept in a freestall barn: 1 pen housed 12 prepartum cows, and 2 pens (each containing 12 cows) housed the postpartum animals. Cows were assigned in an alternating fashion to the postpartum pens. All pens were equipped with 12 lying stalls fitted with a mattress (Pasture Mat; Promat Inc., Woodstock, ON, Canada) and covered with approximately $5 \mathrm{~cm}$ of sand bedding; 6 Insentec feed bins (Insentec BV, Marknesse, the Netherlands) and 1 Insentec water bin. The cow-to-stall ratio was 1:1 throughout the study. Group composition was dynamic, with cows entering and leaving the pre- and postpartum pens, depending on expected and actual calving dates and duration spent in the pen. Prepartum cows were checked multiple times daily for signs of imminent calving. Cows showing signs such as vaginal discharge, milk letdown, or relaxation of the pelvic ligaments were moved to 1 of the 2 individual maternity pens. The maternity pens were deep-bedded with sand and covered with fresh straw; cows stayed here until their first milking. Milking took place twice each day at approximately $0700 \mathrm{~h}$ and $1700 \mathrm{~h}$.

Pre- and postpartum diets were formulated according to NRC (2001) recommendations. Prepartum cows were fed at approximately $0800 \mathrm{~h}$, and postpartum cows were fed twice daily at approximately 0700 and $1600 \mathrm{~h}$. Fresh TMR samples were collected and frozen weekly. Samples were thawed and dried at $60^{\circ} \mathrm{C}$ for 48 $\mathrm{h}$ to determine DM content. Samples were then ground, pooled monthly, and sent to Cumberland Valley Analytical Services Inc. (Maugansville, MD) for analysis (AOAC International, 2005) to determine average $\mathrm{CP}, \mathrm{ADF}, \mathrm{NDF}$, and $\mathrm{NE}_{\mathrm{L}}$ content. Prepartum TMR consisted of $43.9 \%$ corn silage, $34.7 \%$ alfalfa hay, and $21.4 \%$ prelactation concentrate and mineral mix on a DM basis (DM: $44.5 \pm 3.4 \%$; CP: $15.4 \pm 0.9 \%$ of DM; ADF: $32.4 \pm 1.7 \%$ of DM; NDF: $44.1 \pm 2.5 \%$ of $\mathrm{DM} ; \mathrm{NE}_{\mathrm{L}}$ : $\left.1.4 \mathrm{Mcal} / \mathrm{kg}\right)$. Postpartum TMR consisted of $39.7 \%$ mineral and concentrate mix, $32.9 \%$ grass silage, $19.2 \%$ corn silage, and $8.2 \%$ alfalfa hay on a DM basis (DM: $51.4 \pm 3.2 \%$; CP: $18.1 \pm 0.9 \%$ of DM; ADF: $21.1 \pm 1.6 \%$ of DM; NDF: $33.4 \pm 0.9 \%$ of DM; $\left.\mathrm{NE}_{\mathrm{L}}: 1.6 \mathrm{Mcal} / \mathrm{kg}\right)$. Thawed TMR samples were used to determine particle size distribution with the Penn State Particle Separator (Kononoff et al., 2003), consisting of 3 sieves and the bottom pan. The pore sizes of the 3 sieves were $19 \mathrm{~mm}$ (upper), $8 \mathrm{~mm}$ (middle), and 1.18 $\mathrm{mm}$ (lower). The prepartum TMR was composed of $28.3 \%$ of particles $>19 \mathrm{~mm}, 37.1 \%$ of particles $>8 \mathrm{~mm}$, $24.4 \%$ of particles $>1.18 \mathrm{~mm}$, and $10.2 \%$ of particles $<1.18 \mathrm{~mm}$. The postpartum TMR was composed of $20.8 \%$ particles $>19 \mathrm{~mm}, 36.1 \%$ of particles $>8 \mathrm{~mm}$, $30.3 \%$ of particles $>1.18 \mathrm{~mm}$, and $12.8 \%$ of particles $<1.18 \mathrm{~mm}$.

The Insentec system, validated by Chapinal et al. (2007), was used to monitor time spent feeding, duration of feeding, and amount of feed consumed during each visit to a bin. We used a previously validated replacement criterion (Huzzey et al., 2014) to automatically assess social behavior in the form of replacements at the feed bunk using data collected from the Insentec system. A replacement was defined as 1 cow (the actor) replacing another cow (the reactor) at the same feed bin.

Cows were fitted with rumination loggers (HR-Tag; SCR, Netanya, Israel) for continuous recording of rumination activity (for a full description and validation, see Schirmann et al., 2009). Infrared identification units, installed above water bins and at the entrance to the milking parlor, were used to transmit data from the logger to the computer.

Every morning, cows in the prepartum pen had their rectal temperatures taken and were checked for signs of calving, injuries, and visible signs of illness, such as dehydration or lameness. Blood BHB was measured weekly (Iwersen et al., 2009). Body condition was scored weekly using a 5 -point scale in 0.25 increments (adapted from Ferguson et al., 1994).

Postpartum health checks were performed daily after morning milking and consisted of rectal temperature, rumen auscultation (healthy cattle have 1 or 2 primary rumen contractions per min; Divers and Peek, 2008), 
percussion for displaced abomasum (listening for abdominal pings; Radostits et al., 2007), dehydration (skin test, dry mucosal tissue, sunken eyes), and retained placenta (placenta still attached $>24 \mathrm{~h}$ following parturition). Blood BHB was determined 3 times/week (Monday, Wednesday, and Friday). Cows were classified as having SCK when BHB was $\geq 1.2 \mathrm{mmol} / \mathrm{L}$ during the first $14 \mathrm{~d}$ postpartum (Oetzel, 2004; Duffield et al., 2009; McArt et al., 2012a). Metritis diagnosis was based on vaginal discharge, scored twice per week using the evaluated Metricheck (Metricheck, Simpro, New Zealand; Pleticha et al., 2009). Discharge was assessed visually and scored (0 to 4; adapted from Sheldon et al., 2006). Cows with at least 1 score of 3 (clear or cloudy mucus with $>50 \%$ pus) or 4 (watery, red-brown) during the first $21 \mathrm{~d}$ postpartum were classified as having puerperal metritis. Given diurnal variations in fever (Vickers et al., 2010) and the high subjectivity of vaginal discharge odor assessment (Sannmann et al., 2013), fever and odor were not considered. A trained milker assessed cows for clinical mastitis at every milking by checking udders and visually inspecting the milk.

Of the 80 cows enrolled, 7 did not finish the study (sold, severe milk fever, persistent mastitis, or split legs) and 9 cows were removed from the final data set because they were diagnosed with a single health problem that was not metritis or SCK (milk fever, fever, mastitis). Data were grouped according to cows' postpartum health status. Cows that presented no symptoms of health problems were classified as healthy $(\mathrm{n}=20)$. Cows with health problems were classified as having metritis $(\mathrm{n}=18)$, SCK $(\mathrm{n}=9)$, both diseases (metritis+SCK, $\mathrm{n}=9$ ), or $>1$ health problem and not included before (e.g., mastitis and SCK; MULT, $\mathrm{n}=$ 8 ). Cows with retained placenta and metritis were classified as having metritis, given that a retained placenta is a major risk factor for metritis (Paisley et al., 1986). The mean BCS across all sick cows at parturition was $3.29 \pm 0.25$ (mean $\pm \mathrm{SD}$ ); the mean BCS for healthy cows was $3.33 \pm 0.22$.

Data loss of one or more 2-h intervals of rumination data led to the exclusion of the entire day for that animal and resulted in a total loss of $4 \%$ of the data. We performed statistical analyses using SAS software (version 9.3; SAS Institute, Inc., Cary, NC), with cow as the experimental unit. We summarized DMI, feeding time, rumination, and social behavior data by $2-\mathrm{h}$ interval, cow, and day to obtain individual daily values. Feeding rates were calculated by dividing DMI by time spent feeding. Days $-1,0,1$, and 2 relative to calving were excluded, because research has shown that calving and regrouping affect rumination and feeding behavior (Schirmann et al., 2011, 2013). Data were initially plotted to identify differences in behaviors between health categories over time and were then divided into 4 periods: precalving ( $\mathrm{d}-7$ to $\mathrm{d}-2$ ), period 1 ( $\mathrm{d} 3$ to 8 postpartum), period 2 (d 9 to 14 postpartum), and period 3 (d 15 to 20 postpartum). These periods essentially referred to the weeks relative to calving, but because we excluded the days around calving we preferred the term period rather than week. To test for differences between health categories in each of the periods we used a mixed model (PROC MIXED) with cow as a repeated measure and health status as a fixed effect. Parity and the interaction day $\times$ health status were not significant. Day was significant and retained in the model. We used Dunnett's adjustment as a post hoc test to evaluate differences between healthy and sick cows and control for the experimental wise error rate. Residuals were plotted and visually examined to assess normality and homogeneity of variances. Significance was declared at $P \leq 0.05$ and tendency at $P \leq 0.1$.

On average, precalving healthy cows spent $14 \%$ more time ruminating than precalving SCK cows (Figure 1A). We observed no differences in times spent ruminating postpartum. The DMI of precalving healthy cows was 12 and $15 \%$ higher than that of precalving metritis+SCK and SCK cows, respectively (Figure 1B). During period 1, healthy cows consumed on average $15 \%$ more (range 11 to $18 \%$ ) than cows in the other health categories. Healthy cows consumed 8 to $13 \%$ more during period 2. During period 3, healthy cows had a higher DMI than cows with metritis+SCK, but cows with SCK and cows with metritis only tended to differ.

Precalving healthy cows spent on average 18 to $29 \%$ more time feeding than cows with SCK, metritis+SCK, and MULT (Table 1). In period 1, healthy cows spent 13 to $25 \%$ more time feeding than cows in the other health categories. During period 2, healthy cows spent up to $24 \%$ more time feeding than cows with metritis, SCK, and MULT. In period 3, only MULT cows differed from healthy cows and spent close to an hour less feeding $(22 \%)$.

Precalving SCK and MULT cows had a higher feeding rate than healthy cows. Only MULT cows had a higher feeding rate than healthy cows throughout periods 1 to 3. Precalving healthy cows visited the feed bin 18,24 , and $40 \%$ more often than cows in the metritis+SCK, SCK, and MULT groups, respectively. Healthy cows visited the feed bins $14 \%$ more often than SCK cows in period 1 and 36,35 , and $28 \%$ more frequently than MULT cows in periods 1, 2, and 3, respectively.

In the precalving period and period 1 , healthy cows were 31 and $33 \%$ more often successful at replacing another cow at the feed bin than MULT cows (Table 1). Compared with healthy cows, metritis+SCK cows were more often successful at replacing another cow 

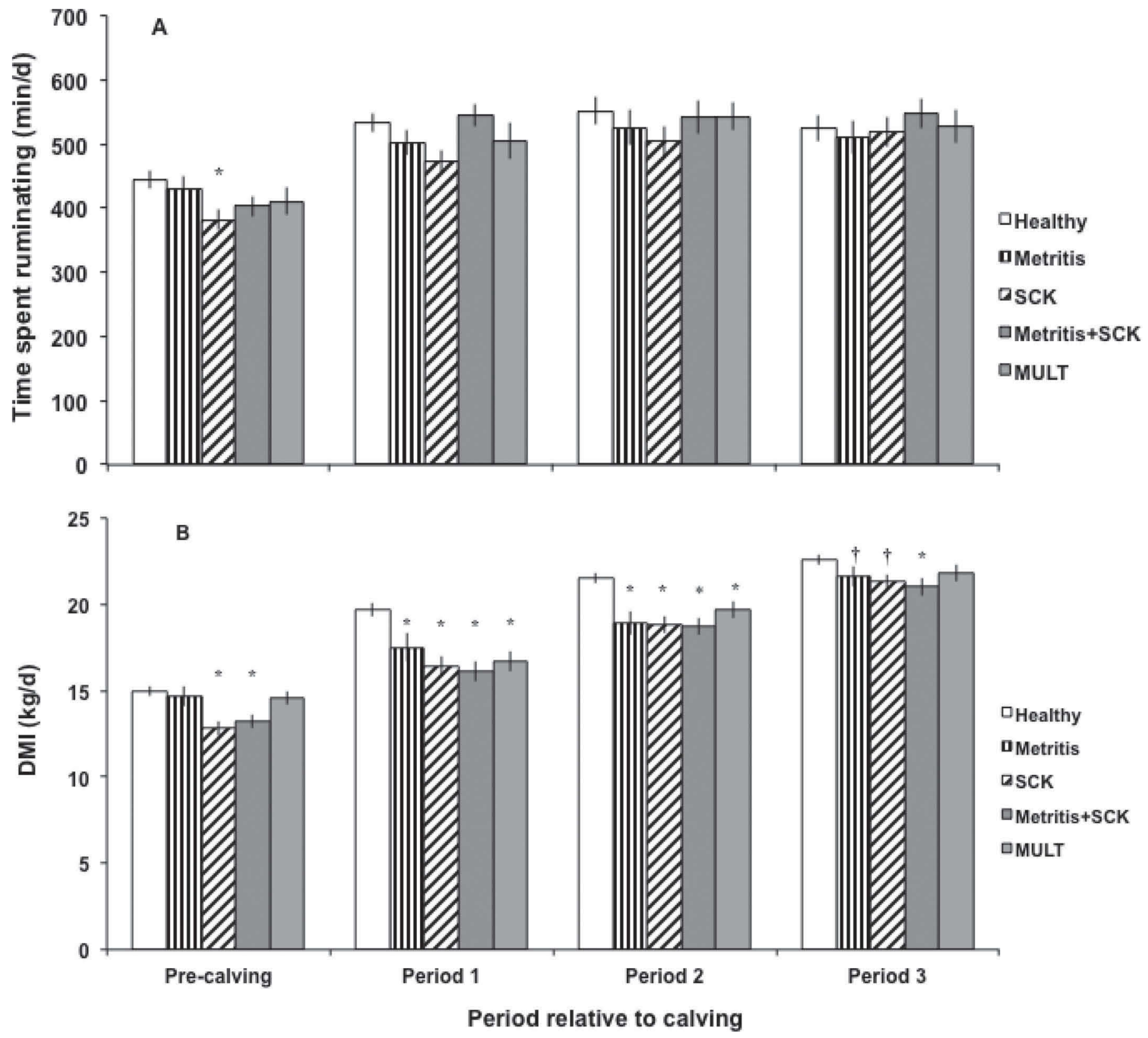

Figure 1. Average daily time spent ruminating (LSM \pm SE; A) and average daily DMI (LSM \pm SE; B) for the 5 health categories: healthy $(\mathrm{n}=20)$, metritis $(\mathrm{n}=18)$, subclinical ketosis (SCK; $\mathrm{n}=9$ ), metritis+SCK $(\mathrm{n}=9)$, and MULT ( $>1$ health problem and not included before; $\mathrm{n}$ $=8$ ) within each period relative to calving (precalving, and periods 1,2 , and 3 ). $\dagger P<0.1, * P<0.05$ : significance levels for differences between healthy cows and each of the other health categories within a period relative to calving.

during period 3. During the precalving period, metritis cows were replaced $33 \%$ more often than healthy cows. At the same time, cows with SCK and MULT were replaced less often than healthy cows. In period 1, SCK and MULT cows were both replaced $42 \%$ less often at the feed bin than healthy cows. MULT cows were also replaced less often during periods $2(43 \%)$ and $3(33 \%)$ than healthy cows. In periods 2 and 3 only,
metritis+SCK cows were replaced 36 and $47 \%$ more often at the feed bin than healthy cows.

This study shows differences in rumination and feeding behavior between healthy cows and cows with health problems in the weeks following parturition. The percentage of cows with metritis reported in the current study (28\%) was within the range of previous work (Machado et al., 2014, 12\%; Patbandha et al., 2012, 
$40 \%)$. The percentage of cows with SCK reported here (14\%) was also within the range of previous work: for example, McArt et al. (2012a) reported a prevalence of $43 \%$, and Liboreiro et al. (2015) described a prevalence of $13 \%$. However, the prevalence of SCK reported in the literature varies, depending on threshold applied (Borchardt and Staufenbiel, 2012), region (Suthar et al., 2013), and management (Heuwieser et al., 2010; Berge and Vertenten, 2014). In our study, excluding metritis+SCK cows, $13 \%$ of animals experienced multiple unrelated health problems. Combined, the percentage of animals with multiple health problems in the present study (27\%) was slightly higher than the $20 \%$ reported by Ospina et al. (2010).

The average precalving and postpartum rumination times for healthy cows of 7.5 and $9 \mathrm{~h} / \mathrm{d}$ were similar to those reported elsewhere (Adin et al., 2009; Soriani et al., 2012; Calamari et al., 2014). We observed no differences between health categories in time spent ruminating during periods 1 to 3 . However, the ob- served precalving difference in rumination activity between healthy animals and animals with SCK was in agreement with Kaufman et al. (2016). Interestingly, Kaufman et al. (2016) reported a tendency toward a decrease in rumination for cows with SCK during wk -1 and +1 relative to calving. Also, Liboreiro et al. (2015) noted a reduction in daily rumination time from calving to d 8 postpartum for cows with SCK. A decrease in rumination time, combined with the onset of clinical disease, has previously been described for lameness (Miguel-Pacheco et al., 2014), mastitis (Siivonen et al., 2011; Fogsgaard et al., 2012), and metabolic changes (Hansen et al., 2003; DeVries et al., 2009). In agreement with these results, our work suggests that monitoring rumination precalving can be useful in identifying cows that will experience health problems, especially SCK, in the days after calving. The early detection of cows with SCK is important; when left untreated, these cows have a higher risk of displaced abomasum and are more likely to be culled within the first 30 DIM (McArt et

Table 1. Least squares means $( \pm \mathrm{SE})$ for feeding and social behavior for cows from each of 5 health categories and for each of the 4 periods investigated

\begin{tabular}{|c|c|c|c|c|c|}
\hline \multirow[b]{2}{*}{ Parameter } & \multicolumn{5}{|c|}{ Health category ${ }^{1}$} \\
\hline & $\begin{array}{l}\text { Healthy } \\
(\mathrm{n}=20)\end{array}$ & $\begin{array}{l}\text { Metritis } \\
(\mathrm{n}=18)\end{array}$ & $\begin{array}{c}\text { SCK } \\
(\mathrm{n}=9)\end{array}$ & $\begin{array}{c}\text { Metritis+SCK } \\
\quad(\mathrm{n}=9)\end{array}$ & $\begin{array}{l}\text { MULT } \\
(\mathrm{n}=8)\end{array}$ \\
\hline \multicolumn{6}{|c|}{ Feeding time $(\min / \mathrm{d})$} \\
\hline Precalving & $236 \pm 5$ & $221 \pm 5$ & $168 \pm 5^{*}$ & $193 \pm 7^{*}$ & $174 \pm 8^{*}$ \\
\hline Period 1 & $197 \pm 4$ & $172 \pm 4^{*}$ & $158 \pm 6^{*}$ & $172 \pm 6^{*}$ & $148 \pm 7^{*}$ \\
\hline Period 2 & $231 \pm 5$ & $204 \pm 7^{*}$ & $202 \pm 7^{*}$ & $214 \pm 6$ & $175 \pm 7^{*}$ \\
\hline Period 3 & $249 \pm 5$ & $236 \pm 5$ & $235 \pm 7$ & $232 \pm 7$ & $195 \pm 8^{*}$ \\
\hline \multicolumn{6}{|c|}{ Feeding rate $(\mathrm{g} / \mathrm{min})$} \\
\hline Precalving & $65 \pm 2$ & $69 \pm 2$ & $81 \pm 2^{*}$ & $70 \pm 2$ & $87 \pm 3^{*}$ \\
\hline Period 1 & $103 \pm 2$ & $107 \pm 2$ & $105 \pm 3$ & $97 \pm 3$ & $115 \pm 8^{*}$ \\
\hline Period 2 & $96 \pm 2$ & $98 \pm 2$ & $96 \pm 3$ & $89 \pm 3$ & $116 \pm 3^{*}$ \\
\hline Period 3 & $93 \pm 2$ & $97 \pm 2$ & $96 \pm 3$ & $94 \pm 3$ & $115 \pm 3^{*}$ \\
\hline \multicolumn{6}{|l|}{ Visits (no./d) } \\
\hline Precalving & $62 \pm 2$ & $60 \pm 2$ & $47 \pm 3^{*}$ & $51 \pm 3^{*}$ & $37 \pm 3^{*}$ \\
\hline Period 1 & $44 \pm 2$ & $43 \pm 2$ & $38 \pm 2^{*}$ & $41 \pm 2$ & $28 \pm 2^{*}$ \\
\hline Period 2 & $46 \pm 2$ & $46 \pm 2$ & $44 \pm 2$ & $45 \pm 2$ & $30 \pm 2^{*}$ \\
\hline Period 3 & $47 \pm 2$ & $49 \pm 2$ & $48 \pm 2$ & $48 \pm 2$ & $34 \pm 3^{*}$ \\
\hline \multicolumn{6}{|c|}{ Replacement actor ${ }^{2}$ (no./d) } \\
\hline Precalving & $13 \pm 1$ & $12 \pm 1$ & $10 \pm 1$ & $12 \pm 1$ & $9 \pm 1^{*}$ \\
\hline Period 1 & $12 \pm 1$ & $12 \pm 1$ & $11 \pm 1$ & $14 \pm 1$ & $8 \pm 1^{*}$ \\
\hline Period 2 & $14 \pm 1$ & $14 \pm 1$ & $15 \pm 2$ & $18 \pm 1 \dagger$ & $10 \pm 2$ \\
\hline Period 3 & $14 \pm 1$ & $15 \pm 1$ & $18 \pm 2$ & $19 \pm 2^{*}$ & $13 \pm 2$ \\
\hline \multicolumn{6}{|c|}{ Replacement reactor ${ }^{3}$ (no./d) } \\
\hline Precalving & $12 \pm 1$ & $16 \pm 1^{*}$ & $7 \pm 1^{*}$ & $11 \pm 1$ & $6 \pm 1^{*}$ \\
\hline Period 1 & $12 \pm 1$ & $13 \pm 1$ & $7 \pm 1 *$ & $14 \pm 1$ & $7 \pm 1^{*}$ \\
\hline Period 2 & $14 \pm 1$ & $16 \pm 1$ & $11 \pm 2$ & $19 \pm 1^{*}$ & $8 \pm 2^{*}$ \\
\hline Period 3 & $15 \pm 1$ & $16 \pm 1$ & $15 \pm 2$ & $22 \pm 2^{*}$ & $10 \pm 2^{*}$ \\
\hline
\end{tabular}


al., 2012b). Furthermore, SCK impairs reproduction, decreasing pregnancy rates at first insemination (Walsh et al., 2007).

In the present study, average precalving and postpartum DMI, time spent feeding, and number of visits to the feed bin for healthy animals were in line with our previous research (Huzzey et al., 2007; Goldhawk et al., 2009; Vickers et al., 2013). However, unlike Huzzey et al. (2007), we did not detect differences in feeding behavior before calving between cows with metritis and healthy cows. This difference may have been due to differences in days included in the analysis, and to scoring of vaginal discharge and inclusion criteria. Differences in diet between studies may also have contributed to differences in feeding behavior, because dietary energy density has been found to influence behavior at the feed bunk (Huzzey et al., 2013). The reduced DMI, lower feeding times, and fewer visits to the feed bin before calving that we observed for cows with SCK may have been caused by malaise without diagnosable illness, and by reduced abdominal space because of the growing fetus. Throughout the study, MULT cows spent less time feeding, fed at a faster rate, and visited the feed bin less often than healthy cows. Interestingly, they also had lower DMI in periods 1 and 2 despite the increase in feeding rate. The MULT cows were less often the receiver of a replacement in all 4 study periods, but the active involvement of MULT cows in a replacement was lower only during the precalving period and period 1 . Other studies have shown that ill and lame cows will sometimes increase feeding rate, likely as a mechanism to maintain intake (González et al., 2008; Norring et al., 2014). We suggest that when cows feel sick, they are less able to compete successfully for access to the feed bunk, and thus use higher feeding rates when they do have access. Previous research has shown that socially subordinate cows, less able to aggressively compete for access to feed, eat at higher rates when they do have access to feed (Proudfoot et al., 2010). In our study, cows in the MULT group not only increased their feeding rate, but also showed an added peak of feed intake in the early afternoon, a time of day when there is otherwise little activity at the feed bunk, possibly providing another way for sick cows to avoid social interactions and competition at the feed bunk. We therefore suggest that cows in the MULT group developed different coping mechanisms, such as an increased feeding rate and feeding at less favorable times, to maintain DMI at a level similar to healthy cows.

Some forms of illness likely reduce appetite, especially at the onset of disease. For example, Fogsgaard et al. (2012) reported that feeding behavior decreased after Escherichia coli mastitis was induced. The differences in postpartum feeding behavior in our study were similar to those observed by Huzzey et al. (2007) and Goldhawk et al. (2009); these studies found lower DMI and feeding times during the first weeks postpartum for cows diagnosed with metritis and SCK, respectively. The cow-to-bin ratio in our study was $2: 1$ for the prepartum and postpartum periods. Using the same ratio of $2: 1$ and a ratio of 1:1, Proudfoot et al. (2009) reported tendencies for lower DMI during the last week prepartum and lower feeding times during the first week postpartum for cows that were overstocked. Interestingly, Hosseinkhani et al. (2008), using the same ratios as Proudfoot et al. (2009), found no differences in DMI for cows during wk -3 and -2 relative to calving. Overall, our results suggest that the ill cows in our study were attempting to avoid competition by increasing feeding rate or feeding at a less favorable time, but they were still motivated to feed. The differences in feeding and social behavior for MULT cows suggest the need for further research on behavioral changes for cows with more than one health problem. Furthermore, our results demonstrate the importance of distinguishing between animals with a single health problem and with multiple health problems.

Automatic monitoring of rumination and feeding behavior in transition dairy cows shows promise for the detection of health problems. Moreover, a combination of both behaviors would likely result in higher detection rates. Monitoring individual rumination behavior with the system used in our study is easier than monitoring individual feed intake and might be more practical and more likely to be implemented on commercial farms.

\section{ACKNOWLEDGMENTS}

We are grateful to the students and staff of the University of British Columbia's Animal Welfare Program (Vancouver, BC, Canada) and Dairy Education and Research Centre (Agassiz, BC, Canada). In particular, we thank Lindsay Collings, Lori Vickers (both of the Animal Welfare Program, University of British Columbia) and Onno Burfeind (Tierklinik für Fortpflanzung, FU Berlin) for their help with the data collection. M.A.G. von Keyserlingk and D.M. Weary are supported by Canada's Natural Sciences and Engineering Research Council (NSERC) Discovery Programs and the NSERC Industrial Research Chair Program, with industry contributions from the Dairy Farmers of Canada (Ottawa, ON, Canada), British Columbia Dairy Association (Burnaby, BC Canada), Westgen Endowment Fund (Milner, BC, Canada), Intervet Canada Corporation (Kirkland, QC, Canada), Zoetis (Kirkland, QC, Canada), Novus International Inc. (Oakville, ON, Canada), BC Cattle Industry Development Fund (Kamloops, BC, Canada), Alberta Milk (Edmonton, AB, 
Canada), Valacta (St. Anne-de-Bellevue, QC, Canada), and CanWest DHI (Guelph, ON, Canada).

\section{REFERENCES}

Adin, G., R. Solomon, M. Nikbachat, A. Zenou, E. Yosef, A. Brosh, A. Shabtay, S. J. Mabjeesh, I. Halachmi, and J. Miron. 2009. Effect of feeding cows in early lactation with diets differing in roughageneutral detergent fiber content on intake behavior, rumination, and milk production. J. Dairy Sci. 92:3364-3373.

AOAC International. 2005. Official Methods of Analysis. 18th rev. ed. AOAC International, Arlington, VA.

Berge, A. C., and G. Vertenten. 2014. A field study to determine the prevalence, dairy herd management systems, and fresh cow clinical conditions associated with ketosis in western European dairy herds. J. Dairy Sci. 97:2145-2154.

Borchardt, S., and R. Staufenbiel. 2012. Evaluation of the use of nonesterified fatty acids and $\beta$-hydroxybutyrate concentrations in pooled serum samples for herd-based detection of subclinical ketosis in dairy cows during the first week after parturition. J. Am. Vet. Med. Assoc. 240:1003-1011.

Bristow, D. J., and D. S. Holmes. 2007. Cortisol levels and anxietyrelated behaviors in cattle. Physiol. Behav. 90:626-628.

Calamari, L., N. Soriani, G. Panella, F. Petrera, A. Minuti, and E. Trevisi. 2014. Rumination time around calving: An early signal to detect cows at greater risk of disease. J. Dairy Sci. 97:3635-3647.

Canadian Council on Animal Care (CCAC). 2009. CCAC Guidelines on: The Care and Use of Farm Animals in Research, Teaching and Testing. CCAC, Ottawa, ON, Canada.

Chapinal, N., D. M. Veira, D. M. Weary, and M. A. G. von Keyserlingk. 2007. Technical note: Validation of a system for monitoring individual feeding and drinking behavior and intake in grouphoused dairy cattle. J. Dairy Sci. 90:5732-5736.

DeVries, T. J., K. A. Beauchemin, F. Dohme, and K. S. SchwartzkopfGenswein. 2009. Repeated ruminal acidosis challenges in lactating dairy cows at high and low risk for developing acidosis: Feeding, ruminating, and lying behavior. J. Dairy Sci. 92:5067-5078.

Divers, T. J., and S. F. Peek. 2008. The clinical examination. Chapter 1 in Rebhuhn's Diseases of Dairy Cattle. 2nd ed. Saunders Elsevier Inc., St. Louis, MO.

Duffield, T. F., K. D. Lissemore, B. W. McBride, and K. E. Leslie. 2009. Impact of hyperketonemia in early lactation dairy cows on health and production. J. Dairy Sci. 92:571-580.

Ferguson, J. D., D. T. Galligan, and N. Thomsen. 1994. Principal descriptors of body condition score in Holstein cows. J. Dairy Sci. $77: 2695-2703$

Fogsgaard, K. K., C. M. Rentved, P. Sørensen, and M. S. Herskin. 2012. Sickness behavior in dairy cows during Escherichia coli mastitis. J. Dairy Sci. 95:630-638.

Goldhawk, C., N. Chapinal, D. M. Veira, D. M. Weary, and M. A. G. von Keyserlingk. 2009. Prepartum feeding behavior is an early indicator of subclinical ketosis. J. Dairy Sci. 92:4971-4977.

González, L. A., B. J. Tolkamp, M. P. Coffey, A. Ferret, and I. Kyriazakis. 2008. Changes in feeding behavior as possible indicators for the automatic monitoring of health disorders in dairy cows. J. Dairy Sci. 91:1017-1028.

González, M., A. K. Yabuta, and F. Galindo. 2003. Behaviour and adrenal activity of first parturition and multiparous cows under a competitive situation. Appl. Anim. Behav. Sci. 83:259-266.

Hansen, S. S., P. Norgaard, C. Pedersen, R. J. Jorgensen, L. S. B. Mellau, and J. D. Enemark. 2003. The effect of subclinical hypocalcaemia induced by $\mathrm{Na}_{2}$ EDTA on the feed intake and chewing activity of dairy cows. Vet. Res. Commun. 27:193-205.

Hasegawa, N., A. Nishiwaki, K. Sugawara, and I. Ito. 1997. The effects of social exchange between two groups of lactating primiparous heifers on milk production, dominance order, behaviour and adrenocortical response. Appl. Anim. Behav. Sci. 51:15-27.

Heuwieser, W., M. Iwersen, J. Gossellin, and M. Drillich. 2010. Short communication: Survey of fresh cow management practices of dairy cattle on small and large commercial farms. J. Dairy Sci. 93:1065-1068.

Hosseinkhani, A., T. J. DeVries, K. L. Proudfoot, R. Valizadeh, D. M. Veira, and M. A. G. von Keyserlingk. 2008. The effects of feed bunk competition on the feed sorting behavior of close-up dry cows. J. Dairy Sci. 91:1115-1121.

Huzzey, J. M., J. A. Fregonesi, D. M. Weary, and M. A. G. von Keyserlingk. 2013. Sampling behavior of dairy cattle: Effects of variation in dietary energy density on behavior at the feed bunk. J. Dairy Sci. 96:247-256.

Huzzey, J. M., D. M. Veira, D. M. Weary, and M. A. G. von Keyserlingk. 2007. Prepartum behavior and dry matter intake identify dairy cows at risk for metritis. J. Dairy Sci. 90:3220-3233.

Huzzey, J. M., D. M. Weary, B. Y. F. Ziau, and M. A. G. von Keyserlingk. 2014. Short communication: Automatic detection of social competition using an electronic feeding system. J. Dairy Sci. 97:2953-2958.

Iwersen, M., U. Falkenberg, R. Voigtsberger, D. Forderung, and W. Heuwieser. 2009. Evaluation of an electronic cowside test to detect subclinical ketosis in dairy cows. J. Dairy Sci. 92:2618-2624.

Kaufman, E. I., S. J. LeBlanc, B. W. McBride, T. F. Duffield, and T. J. DeVries. 2016. Association of rumination time with subclinical ketosis in transition dairy cows. J. Dairy Sci. 99:5604-5618.

Kononoff, P. J., A. J. Heinrichs, and D. R. Buckmaster. 2003. Modification of the Penn State forage and total mixed ration particle separator and the effects of moisture content on its measurements. J. Dairy Sci. 86:1858-1863.

Liboreiro, D. N., K. S. Machado, P. R. B. Silva, M. M. Maturana, T. K. Nishimura, A. P. Brandão, M. I. Endres, and R. C. Chebel. 2015. Characterization of peripartum rumination and activity of cows diagnosed with metabolic and uterine diseases. J. Dairy Sci. 98:6812-6827.

Machado, V. S., M. L. S. Bilcalho, R. O. Gilbert, and R. C. Bicalho. 2014. Short communication: Relationship between natural antibodies and postpartum uterine health in dairy cows. J. Dairy Sci. 97:7674-7678

McArt, J. A. A., D. V. Nydam, and G. R. Oetzel. 2012a. Epidemiology of subclinical ketosis in early lactation dairy cattle. J. Dairy Sci. 95:5056-5066.

McArt, J. A. A., D. V. Nydam, and G. R. Oetzel. 2012b. A field trial on the effect of propylene glycol on displaced abomasum, removal from herd, and reproduction in fresh cows diagnosed with subclinical ketosis. J. Dairy Sci. 95:2505-2512.

Miguel-Pacheco, G. G., J. Kaler, J. Remnant, L. Cheyne, C. Abbott, A. P. French, T. P. Pridmore, and J. N. Huxley. 2014. Behavioural changes in dairy cows with lameness in an automatic milking system. Appl. Anim. Behav. Sci. 150:1-8.

Norring, M., J. Häggeman, H. Simojoki, P. Tamminen, C. Winckler, and M. Pastell. 2014. Short communication: Lameness impairs feeding behavior of dairy cows. J. Dairy Sci. 97:4317-4321.

NRC. 2001. Nutrient Requirements of Dairy Cattle. 7th rev. ed. Natl Acad. Press, Washington, DC.

Oetzel, G. R. 2004. Monitoring and testing dairy herds for metabolic disease. Vet. Clin. North Am. Food Anim. Pract. 20:651-674.

Ospina, P. A., D. V. Nydam, T. Stokol, and T. R. Overton. 2010. Evaluation of nonesterified fatty acids and $\beta$-hydroxybutyrate in transition dairy cattle in the northeastern United States: Critical thresholds for prediction of clinical diseases. J. Dairy Sci. 93:546554.

Paisley, L. G., D. Mickelsen, and P. B. Anderson. 1986. Mechanisms and therapy for retained fetal membranes and uterine infections of cows: A review. Theriogenology 25:353-381.

Patbandha, T. K., T. K. Mohanty, S. S. Layek, A. Kumaresan, and K. Behera. 2012. Application of pre-partum feeding and social behaviour in predicting risk of developing metritis in crossbred cows. Appl. Anim. Behav. Sci. 139:10-17.

Pleticha, S., M. Drillich, and W. Heuwieser. 2009. Evaluation of the Metricheck device and the gloved hand for the diagnosis of clinical endometritis in dairy cows. J. Dairy Sci. 92:5429-5435.

Proudfoot, K. L., D. M. Veira, D. M. Weary, and M. A. G. von Keyserlingk. 2009. Competition at the feed bunk changes the feeding, 
standing, and social behavior of transition dairy cows. J. Dairy Sci. 92:3116-3123.

Proudfoot, K. L., D. M. Weary, and M. A. G. von Keyserlingk. 2010. Behavior during transition differs for cows diagnosed with claw horn lesions in mid lactation. J. Dairy Sci. 93:3970-3978.

Radostits, O. M., C. C. Gay, K. W. Hinchcliff, and P. D. Constable. 2007. Veterinary Medicine: A Textbook of the Diseases of Cattle, Horses, Sheep, Pigs and Goats. 10th ed. Saunders Ltd., Philadelphia, PA.

Sannmann, I., O. Burfeind, V. Suthar, A. Bos, M. Bruins, and W. Heuwieser. 2013. Technical note: Evaluation of odor from vaginal discharge of cows in the first 10 days after calving by olfactory cognition and an electronic device. J. Dairy Sci. 96:5773-5779.

Schirmann, K., N. Chapinal, D. M. Weary, W. Heuwieser, and M. A. G. von Keyserlingk. 2011. Short-term effects of regrouping on behavior of prepartum dairy cows. J. Dairy Sci. 94:2312-2319.

Schirmann, K., N. Chapinal, D. M. Weary, L. Vickers, and M. A. G. von Keyserlingk. 2013. Short communication: Rumination and feeding behavior before and after calving in dairy cows. J. Dairy Sci. 96:7088-7092.

Schirmann, K., M. A. G. von Keyserlingk, D. M. Weary, D. M. Veira, and W. Heuwieser. 2009. Technical note: Validation of a system for monitoring rumination in dairy cows. J. Dairy Sci. 92:6052-6055.

Sheldon, I. M., G. S. Lewis, S. LeBlanc, and R. O. Gilbert. 2006. Defining postpartum uterine disease in cattle. Theriogenology 65:1516-1530.

Siivonen, J., S. Taponen, M. Hovinen, M. Pastell, B. Joop Lensink, S. Pyörälä, and L. Hanninen. 2011. Impact of acute clinical mastitis on cow behaviour. Appl. Anim. Behav. Sci. 132:101-106.
Soriani, N., E. Trevisi, and L. Calamari. 2012. Relationships between rumination time, metabolic conditions, and health status in dairy cows during the transition period. J. Anim. Sci. 90:4544-4554.

Suthar, V. S., J. Canelas-Raposo, A. Deniz, and W. Heuwieser. 2013. Prevalence of subclinical ketosis and relationships with postpartum diseases in European dairy cows. J. Dairy Sci. 96:2925-2938.

Vickers, L. A., O. Burfeind, M. A. G. von Keyserlingk, D. M. Veira, D M. Weary, and W. Heuwieser. 2010. Technical note: Comparison of rectal and vaginal temperatures in lactating dairy cows. J. Dairy Sci. 93:5246-5251.

Vickers, L. A., D. M. Weary, D. M. Veira, and M. A. G. von Keyserlingk. 2013. Feeding a higher forage diet prepartum decreases incidences of subclinical ketosis in transition dairy cows. J. Anim. Sci. 91:886-894.

von Keyserlingk, M. A. G., and D. M. Weary. 2010. Feeding behavior of dairy cattle: Measures and applications. Can. J. Anim. Sci. 90:303-309.

Walsh, R. B., J. S. Walton, D. F. Kelton, S. J. LeBlanc, K. E. Leslie, and T. F. Duffield. 2007. The effect of subclinical ketosis in early lactation on reproductive performance of postpartum dairy cows. J. Dairy Sci. 90:2788-2796.

Weary, D. M., J. M. Huzzey, and M. A. G. von Keyserlingk. 2009. Board-invited review: Using behavior to predict and identify ill health in animals. J. Anim. Sci. 87:770-777. 